\title{
Spray scheduling of fungicide Difenoconazole 25EC for the management of Stemphylium blight of onion (Allium cepa L.)
}

\section{Bhavya Mishra*}

Department of Plant Pathology, Govind Ballabh Pant University of Agriculture and Technology, Pantnagar-263145 (Uttarakhand), India

\section{R.P. Singh}

Department of Plant Pathology, Govind Ballabh Pant University of Agriculture and Technology, Pantnagar-263145 (Uttarakhand), India

*Corresponding author. E-mail: mishrabhavya239@gmail.com

\begin{abstract}
A field experiment was conducted during rabi season of 2015 at the Vegetable Research Centre of G.B. Pant University of Agricuture ant Technology, Pantnagar to evaluate the effect of different number of fungicidal sprays of a standard fungicide Difenoconazole 25EC for the management of Stemphylium blight of onion caused by Stemphylium vesicarium (Wallr.) Simmons. The experiment was laid out in RBD and different number of foliar sprays of difenoconazole viz. 3, 4, 5 and 6 sprays was tested starting from 15 and 30 days after transplanting right up to 90 days after transplanting with three replications of each treatment. Results of the experiment revealed that 5 foliar sprays were most effective giving the highest per cent disease control $(23.37 \%)$ followed by 6 sprays. The highest marketable bulb yield $\left(22.82 \mathrm{t} \mathrm{ha}^{-1}\right)$ was also obtained in the treatment with 5 sprays. The economic analysis of treatments revealed that 5 sprays gave the maximum net return due to treatment ( $\left.₹ 68,400 \mathrm{ha}^{-1}\right)$ and highest percent avoidable loss $(29.97 \%)$, along with maximum net benefit-cost $(\mathrm{B}: \mathrm{C})$ ratio of 5.64 , followed by 4 sprays. Therefore, 5 sprays of Difenoconazole $25 \mathrm{EC}$ at the rate of $125 \mathrm{~g}$ a.i. ha ${ }^{-1}$ was found as the most effective and economical management strategy against Stemphylium blight of onion under tarai region of Uttarakhand.
\end{abstract}

Keywords: Difenoconazole, Economics, Management, Spray scheduling, Stemphylium

\section{Article Info}

DOI:10.31018/jans.v10i3.1829 Received: July 10, 2018

Revised: July 24, 2018

Accepted: August 7, 2018

\section{How to Cite}

Mishra, B. and Singh, R.P. (2018). Spray scheduling of fungicide Difenoconazole $25 \mathrm{EC}$ for the management of Stemphylium blight of onion (Allium cepa L.) Journal of Applied and Natural Science, 10(3): $971-975$

\section{INTRODUCTION}

Onion (Allium cepa) a bulbous, biennial herb, is one of the most important vegetable crops grown through out the world and in India. It is the most widely cultivated species of the genus Allium. India is the second largest producer of onion in the world with an area of 1320.13 thousand hectare under onion cultivation with a production of 20931.25 thousand MT, but the productivity is 15.86 tonnes per hectare, which is much less than many other countries (NHRDF, 2015). Among the various reasons, diseases and pests are important constraints in onion production. The crop is attacked by many diseases, which cause yield losses and also result in deteriorating the quality and export potential of the production. Stemphylium blight caused by Stemphylium vesicarium (Wallr.) Simmons is one such disease, which was not a major economic threat earlier, but has become a serious problem throughout the country since recent past, especially in Northern and Eastern India. Surveys conducted by NHRDF indicated that Stemphylium blight was more severe in the winter/summer than in the rainy season with 1.3-100\% incidence (Gupta et al., 1994) and sometimes may even cause $100 \%$ crop losses (Singh et al., 1992). Leaf blight often causes premature defoliation the crop and makes it more susceptible to secondary and post-harvest infections. Disease intensity is higher in seed crop than in bulb crop. Various management strategies like cultural practices, field sanitation, and biological control can be adopted, but all these methods are effective only when employed well in advance as precautionary measure (Kata, 2000). Once the disease has appeared, chemical control offers a good choice to grower for managing the disease as they have the advantage of providing quick, effective and economic management. Many fungicides have been tested for the management of Stemphylium blight of onion. Mancozeb 75 WP (@ $0.2 \%$ ) was found effective against Stemphylium blight (Pandey et al., 2008). Carbendazim, copper oxychloride, difenoconazole, chlorothalonil and hexaconozole have been reported, in the order of their merit as effective in the management of the Stemphylium blight and Alternaria blight of onion, 
potato, mustard and other crops by Gorawar and Hegde (2005) and Kumari et al. (2006). However, presently only 6 registered fungicides are recommended for the use in onion crop viz. difenoconazole 25EC, kitazin 48EC, mancozeb 75WP, tebuconazole 25.9EC, zineb 75WP and metiram+pyraclostrobin 60WG (CIBRC, 2016).

Chander et al. (2004) have tested different fungicides against onion leaf blight and reported the superiority of triazoles under in vitro as well as field conditions, and out of the three triazoles, they found tebuconazole to be the most effective against $S$. botryosum, followed by difenoconazole and hexaconazole. For the present study, difenoconazole 25EC (Score) was selected as the standard fungicide because at the time of the study, it was the only systemic fungicide recommended for the use in onion crop. Since yield and quality parameters are the main focal point of any agronomic practice, therefore whether the applied disease control measures are effective or not, is often judged by the final harvested produce. So the effect of application frequency on the yield of the produce was also assessed. Moreover, while using fungicides, their economic aspects are of utmost importance. Triazoles have been found effective and economically superior in various crop pathosystems viz. fruit rot disease of chilli (Kumbhar and More, 2013), groundnut diseases (Sunkad et al., 2005). Since the studies on working out the optimum number of sprays of a fungicide are quite limited, therefore, the present study was undertaken to find out the number of sprays of a standard fungicide (Difenoconazole 25EC) required under field conditions for the economic management of Stemphylium blight of onion. The economics analysis of different number of sprays was also done.

\section{MATERIALS AND METHODS}

Field experiment was conducted at Vegetable Research Centre of G.B. Pant University of Agriculture and Technology, Pantnagar, Uttarakhand during rabi crop season in 2014-15 using Randomized Block Design (RBD) with the aim to optimize spray schedule of recommended fungicide Difenoconazole $25 \%$ EC @ $500 \mathrm{~mL} \mathrm{ha}^{-1}(0.1 \%)$ in order to find out the appropriate number of sprays required for managing Stemphylium blight of onion. For this experiment, onion variety Nasik Red was taken and different number of sprays viz. 3, 4, 5 and 6 sprays were given as per given details in Table 2 and each treatment was replicated thrice.

Observations on disease severity were recorded one week after each spray. Addition of an insecticide targeting onion thrips and sticker for better coverage was kept common with each fungicide spray. Disease severity in field was monitored one week after spraying, on ten selected plants per plot in three replicated plots at fifteen days interval using 0-5 scale (Table 1) given by Sharma (1986). Percent disease index (PDI) was calculated by the following formula given by Wheeler (1969).

$$
\mathrm{PDI}=\frac{\text { Sum of all disease ratings }}{\text { Total number of leaves } \times \text { maximum rating value }} \times 100
$$

Eq. No. 1

$\%$ disease control (PDC) was worked out as:

$$
\mathrm{PDC}=\frac{\text { Severity in control }- \text { Severity in treatment }}{\text { Severity in control }} \times 100
$$

Eq. No. 2

Harvesting of each treatment was done separately and the yield and bulb size was recorded. Total yield was recorded and marketable yield was calculated by discarding those bulbs which were having bolters, or were highly deformed or rotten and of unacceptable, non-marketable quality. Grading was done on the basis of bulb size into three grades viz. A (diameter more than $55 \mathrm{~mm}$ ), B (diameter $45-55 \mathrm{~mm}$ ) and $C$ (diameter less than $45 \mathrm{~mm})$.

For working out the economics of number of sprays, following information was used:

Standard fungicide used was Difenoconazole $25 \%$ EC (Score)

Cost of fungicide $=` 900$ per $250 \mathrm{ml}$

Labour required for spray in 1 ha land area $=3$

Percent Avoidable Loss $=\frac{\text { Marketableyieldin treatment }- \text { Control }}{\text { Marketableyield in treatment }} \times 100$

Labour charges $=$ ` 209 per day

Rate of sale of onion in market $=` 10$ per kg

Return due to treatment $=$ Gross return in treatment - Gross return in control

Net return due to treatment $=$ Return due to treatment - Cost of treatment

Net benefit $: \operatorname{cost}(\mathrm{B}: \mathrm{C})$ ratio $=\frac{\text { Net return due to treatment }}{\text { Cost of treatment }}$

Eq. No. 4

Statistical Analysis: The results of the field experiment were statistically analyzed using the statistical package developed by GBPUAT, Pantnagar (STPR 3). The analysis of replicated data on

Table 1. Disease rating scale used to record the severity of Stemphylium blight in the field.

\begin{tabular}{ll}
\hline Rating & Description of disease progress \\
\hline 0 & $\begin{array}{l}\text { No disease symptom } \\
\text { A few spots towards tip covering } 10 \text { percent } \\
1\end{array}$ \\
2 & $\begin{array}{l}\text { leaf area } \\
\text { Several purplish brown patches covering }\end{array}$ \\
3 & $\begin{array}{l}\text { Several patches with paler outer zone cov- } \\
\text { ering upto } 40 \text { percent leaf area } \\
\text { Leaf streaks covering upto } 75 \text { percent leaf } \\
\text { area or breaking of the leaves from center } \\
\text { Complete drying of the leaves or breaking of } \\
\text { leaves from center }\end{array}$ \\
5 &
\end{tabular}


Mishra, B. and Singh, R.P. / J. Appl. \& Nat. Sci. 10 (3): 971 - 975 (2018)

Table 2. Details of the spray schedule followed in field from 15 to 90 days after transplanting.

\begin{tabular}{|c|c|c|c|c|c|c|}
\hline Total sprays & 15 DAT & 30 DAT & 45 DAT & 60 DAT & 75 DAT & 90 DAT \\
\hline 3 & - & - & + & + & + & - \\
\hline 4 & - & - & + & + & + & + \\
\hline 5 & - & + & + & + & + & + \\
\hline 6 & + & + & + & + & + & + \\
\hline
\end{tabular}

DAT = Days after transplanting, + spray was given, - spray was not given

Table 3. Effect of number of sprays on disease severity of Stemphylium blight of onion.

\begin{tabular}{|c|c|c|c|c|c|c|c|c|c|c|c|c|}
\hline \multirow[b]{2}{*}{$\begin{array}{l}\text { Treat- } \\
\text { ments }\end{array}$} & \multicolumn{6}{|c|}{ Percent disease index* } & \multicolumn{6}{|c|}{ Percent disease control } \\
\hline & $\begin{array}{l}15 \\
\text { DAT }\end{array}$ & $\begin{array}{l}30 \\
\text { DAT }\end{array}$ & $\begin{array}{l}45 \\
\text { DAT }\end{array}$ & $\begin{array}{l}60 \\
\text { DAT }\end{array}$ & $\begin{array}{l}75 \\
\text { DAT }\end{array}$ & $\begin{array}{l}90 \\
\text { DAT }\end{array}$ & $\begin{array}{l}15 \\
\text { DAT }\end{array}$ & $\begin{array}{l}30 \\
\text { DAT }\end{array}$ & $\begin{array}{l}45 \\
\text { DAT }\end{array}$ & $\begin{array}{l}60 \\
\text { DAT }\end{array}$ & $\begin{array}{l}75 \\
\text { DAT }\end{array}$ & $\begin{array}{l}90 \\
\text { DAT }\end{array}$ \\
\hline 3 sprays & 4.54 & 9.52 & 12.20 & 35.16 & 54.60 & 80.23 & 1.59 & 1.14 & 36.92 & 41.74 & 34.07 & 5.90 \\
\hline 4 sprays & 4.57 & 9.48 & 10.86 & 33.94 & 55.68 & 76.66 & 0.94 & 1.52 & 43.87 & 43.76 & 32.76 & 10.09 \\
\hline 5 sprays & 4.46 & 4.37 & 7.41 & 27.50 & 51.22 & 65.34 & 3.47 & 54.59 & 61.69 & 54.44 & 38.15 & 23.37 \\
\hline 6 sprays & 0.45 & 2.18 & 4.95 & 24.05 & 45.01 & 66.29 & 90.32 & 77.33 & 74.39 & 60.16 & 45.64 & 22.25 \\
\hline Check & 4.62 & 9.63 & 19.34 & 60.35 & 79.51 & 85.26 & - & - & 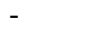 & - & - & - \\
\hline S.Em \pm & 0.94 & 0.96 & 0.68 & 2.81 & 1.25 & 1.75 & & & & & & \\
\hline$C D(p=0.05)$ & N.S. & 3.12 & 2.21 & 9.16 & 4.08 & 5.70 & & & & & & \\
\hline
\end{tabular}

*all values are mean of three replications

Table 4. Effect of number of fungicide sprays on the yield of onion.

\begin{tabular}{|c|c|c|c|c|c|}
\hline \multirow{2}{*}{ Treatment } & \multirow{2}{*}{ Total yield $^{*}\left(\mathrm{t} \mathrm{ha}^{-1}\right)$} & \multirow{2}{*}{ Marketable yield $\left(\mathrm{t} \mathrm{ha}^{-1}\right)$} & \multicolumn{3}{|c|}{ Bulb grade (\%) } \\
\hline & & & $\mathrm{A}(>55 \mathrm{~mm})$ & B (45-55mm) & $\mathrm{C}(<45 \mathrm{~mm})$ \\
\hline 3 sprays & 22.69 & 22.01 & 5.73 & 18.62 & 75.65 \\
\hline 4 sprays & 20.02 & 19.04 & 7.45 & 17.10 & 75.45 \\
\hline 5 sprays & 23.94 & 22.82 & 10.15 & 19.17 & 70.68 \\
\hline 6 sprays & 19.42 & 18.79 & 9.34 & 18.34 & 72.32 \\
\hline Check & 16.32 & 15.08 & 1.95 & 16.50 & 81.55 \\
\hline S.Em \pm & 1.34 & 1.20 & & & \\
\hline$C D(p=0.05)$ & 4.38 & 3.92 & & & \\
\hline
\end{tabular}

*all values are mean of three replications

Table 5. Economics of number of fungicide sprays.

\begin{tabular}{|c|c|c|c|c|c|c|c|}
\hline $\begin{array}{l}\text { Treat- } \\
\text { ment }\end{array}$ & $\begin{array}{l}\text { Marketa- } \\
\text { ble Yield } \\
\left(\mathrm{t} \mathrm{ha}^{-1}\right)\end{array}$ & $\begin{array}{l}\text { Percent } \\
\text { avoidable } \\
\text { losses }\end{array}$ & $\begin{array}{l}\text { Gross Re- } \\
\text { turn } \\
\left(\mathrm{ha}^{-1}\right)\end{array}$ & $\begin{array}{l}\text { Net Re- } \\
\text { turn ( ha- } \\
\text { 1) }\end{array}$ & $\begin{array}{l}\text { Cost of } \\
\text { Treatment } \\
\left(\mathrm{ha}^{-1}\right)\end{array}$ & $\begin{array}{l}\text { Net Return } \\
\text { due to treat- } \\
\text { ment }\left(\mathrm{ha}^{-1}\right)\end{array}$ & $\begin{array}{l}\text { Benefit : } \\
\text { cost ratio }\end{array}$ \\
\hline 3 sprays & 19.04 & 16.07 & 190400.00 & 30600.00 & 7281.00 & 23319.00 & 4.20 \\
\hline 4 sprays & 21.01 & 23.94 & 210100.00 & 50300.00 & 9708.00 & 40592.00 & 5.18 \\
\hline 5 sprays & 22.82 & 29.97 & 228200.00 & 68400.00 & 12135.00 & 56265.00 & 5.64 \\
\hline 6 sprays & 18.79 & 14.95 & 187900.00 & 28100.00 & 14562.00 & 13538.00 & 1.93 \\
\hline Check & 15.98 & - & 159800.00 & - & - & - & - \\
\hline
\end{tabular}

*Details of calculations mentioned in Materials and Method disease severity and yield was done as per RBD.

\section{RESULTS AND DISCUSSION}

Effect on disease severity: Three, four, five and six sprays of standard fungicide Difenoconazole $25 \%$ EC @ $125 \mathrm{~g}$ a.i. ha ${ }^{-1}$ given as different treatments at 15 days interval were found significantly $(p=0.05)$ effective in reducing the disease severity over check (Table 2). Within the treatments, disease severity at all observations was found highest in case of 3 sprays and least in case of 6 sprays. However, at 90 days after transplanting (DAT), the disease severity was least $(65.34 \%)$ in 5 sprays. Therefore, at the end of the crop season, maximum per cent disease control (PDC) was given by 5 sprays $(23.37 \%)$, followed by 6 sprays $(22.25 \%)$. Initially, at 15 DAT, disease severity was minimum in 6 sprays $(0.45 \%)$. All the treatments were found non-significant in reducing the disease severity, except 6 sprays. At 30 DAT, disease severity was minimum in 6 sprays and treatments of 5 and 6 sprays were statistically at par with each other at 30 DAT. At 45 DAT, disease severity was least in 6 sprays while, 3 and 4 sprays were found statistically at par. At 60 DAT, highest PDC was offered by 6 sprays and 4,5 and 6 sprays were found statistically at par with each other. At 75 DAT, highest PDC was in 6 sprays. At 90 DAT, disease severity was minimum in 5 sprays $(65.34 \%)$ and treatments of 5 and 6 sprays were statistically at par. It is evident from the results that, 5 and 6 sprays provided maximum disease control. Between these two, 5 sprays showed better disease control as well as higher yield. So it can be preferred over 6 sprays as it would be more economical. Aujla et al. (2013) have used three sprays at 10 days interval in onion for the management of purple blotch. Bhatia and Chahal (2014) used four foliar applications to test the fungicides 
(Tebuconazole, Propiconazole) for management of Stemphylium blight of onion (Allium cepa L.). Four sprays were applied at 7 days interval by Shahiduzzaman et al. (2015) for testing the efficacy of fungicides to control Stemphylium blight (Stemphylium botryosum) of lentil. They reported 4 sprays of Rovral (iprodione) at the rate of $0.2 \%$ at 7 days interval was effective in managing Stemphylium blight of lentil. Huq and Khan (2007) while testing the in-vivo efficacy of different fungicides in controlling stemphylium blight of lentil tested them with four sprays at 15 days interval. Shahnaz et al. (2012) have used three sprays of fungicides at 15 days interval for their study on integrated disease management of foliar blight disease of onion. Thus, many scientists have tested various spraying schedules but the economic aspects of spray scheduling are rarely discussed. Although general recommendation of any fungicide is 3 sprays keeping in mind the cost of plant protection, but on the basis of present study it was observed that the disease pressure was very high in the tarai region and 3 sprays were not sufficient for managing the disease. Moreover, the disease initiates very early, from the nursery stage itself. So, initiating the control measures later in the season would not be sufficient. Thus, it is suggested that if one can go for 5 sprays, then it will be more beneficial.

Effect on yield: Yield and quality parameters are the main focal point of any agronomic practice. Results presented in Table 3 shows the effect of number of sprays on the yield and quality of onion bulbs. Miller et al. (1986) studied the effects of number and timing of chlorothalonil applications on onion yield and reported that bulb yields decreased linearly as the number of chlorothalonil applications increased. So, it was also important that it the effect of number of sprays be considered in the present study. The data revealed that the lowest total and marketable yield was in check $\left(16.32 \mathrm{t} \mathrm{ha}^{-1}\right.$ and $\left.15.98 \mathrm{t} \mathrm{ha}^{-1}\right)$. All the treatments were found significantly superior to check. Gupta and Gupta (2014) have also observed propiconazole, tebuconazole and mancozeb as effective against $S$. vesicarium by increasing bulb yield in onion. Similar findings have been reported in case of mancozeb against $S$. vesicarium in garlic (Kumar et al., 2011). These findings support our study that fungicide application not only manages the Stemphylium blight but also increases the yield of onion. Within the treatment highest marketable yield was found in five sprays $\left(22.82 \mathrm{t} \mathrm{ha}^{-1}\right)$ and minimum yield was in six sprays $\left(18.79 \mathrm{t} \mathrm{ha}^{-1}\right)$. It shows that if the number of sprays are increased beyond 5, then it may lead to reduction in onion yield. Similar effects have been found by chlorothalonil application in onion (Miller et.al, 1986). Highest share of A grade bulbs in marketable yield was found in five sprays $(10.15 \%)$ and the least in check (1.95\%). The bulbs with greater size and better quality are expected to fetch higher prices in the market and therefore a treatment that increases the proportion of A grade bulbs is expected to ensure higher economic returns. Although, the highest yield was recorded from 5 sprays but there was no significant difference between the treatments and all the number of sprays were found to be statistically at par. Therefore, solely on the basis oy yield, no single treatment can be argued to be superior. However, hen yield and disease management are considered together, it is evident that 5 sprays gave significantly better results.

Economics of treatments: The theme of fungicidal control of plant diseases should always be emphasized on economy of the fungicide.The data in Table 4 shows the economics analysis of different number of fungicidal sprays. The data revealed that treatment having five sprays is the most effective and economical having highest return due to treatment ( $₹ 68,400 \mathrm{ha}^{-1}$ ) and maximum net benefit-cost $(B: C)$ ratio of 5.64. The maximum yield and highest percent of avoidable losses $(29.97 \%)$ was also obtained in five sprays. Second most economical treatment was four sprays having $\mathrm{B}: \mathrm{C}$ ratio of 5.28. Machenahalli and Nargund (2015) studied the effect of fungicides on the management of die-back and fruit rot of chilli and reported that the least incidence of die back and fruit rot along with highest yield and $B: C$ ratio was observed with 4 sprays of difenconazole $25 \mathrm{EC}$ at 15 days interval. Six sprays provided better disease control but was found to be uneconomical as it gave lower yield $\left(18.79 \mathrm{t} \mathrm{ha}^{-1}\right)$ and thus led to a net $B: C$ ratio of only 1.93 . It is evident from the above findings that 5 sprays are most suitable and effective in all aspects. Increasing the number of sprays beyond 5 does not necessarily result in better economic returns, though it may be superior in reducing the disease severity, but simultaneously the cost also increases manifolds.

\section{Conclusion}

Based on the above findings, application of 5 sprays was found to be most effective in providing disease control. The yield data and economics of sprays also supported that 5 sprays gave the maximum net return due to treatment (56265.00 ₹ $\mathrm{ha}^{-1}$ ) and highest percent avoidable loss (29.97 $\%)$. Therefore, when yield of produce along with the economics of treatment and disease management is considered together, 5 sprays of Difenoconazole 25EC @ $125 \mathrm{~g}$ a.i. ha ${ }^{-1}$ can be recommended as an effective and economical management strategy against Stemphylium blight of onion under tarai region of Uttarakhand.

\section{ACKNOWLEDGEMENTS}

Authors are thankful to the Department of Plant 
Pathology, G.B. Pant University of Agriculture and Technology, Pantnagar (Uttarakhand) for providing the necessary field research facilities during the present studies and furnishing the investigation with valuable information.

\section{REFERENCES}

1. Aujla, I.S., Amrate, P.K., Kumar, P. and Thind, T.S. (2013). Efficacy of some new fungicides in controlling purple blotch of onion under Punjab conditions. Pl. Dis. Res. 28(2): 171-173.

2. Bhatia, J.N. and Chahal, D. (2014). Studies on effectiveness of certain new fungicides in controlling stemphylium blight of onion seed crop. Agric. Sci. Dig. 34 (3): 237-239.

3. Chander, M., Thind, T.S., Prem, R. and Arora, J.K. (2004). Promising activity of triazoles and other fungicides against fruit rot of chilli and Stemphylium blight of onion. PI. Dis. Res. 19 (2): 200-203.

4. CIBRC. (2016). Major uses of pesticides: Fungicides. Central Insecticide Board \& Registration Committee, Directorate of Plant Protection, Quarantine \& Storage. Retrieved on January, 182006 from http:// cibrc.gov.in/mup.htm

5. Gorawar, M.M. and Hegde, Y.R. (2005). Management of leaf blight of turmeric caused by Alternaria alternata. Souvenir cum Abstract: National symp. on crop disease management in dryland agriculture. Marathwada Agriculture University, Parbhani (M.S.) India.

6. Gupta, R.C. and Gupta, R.P. (2014). Epidemiological studies on Stemphylium vesicarium causing Stemphylium blight disease of onion (Allium cepa L.). Indian J. Agric. Sci. 84 (9): 1091-1095.

7. Gupta, R.P., Srivastava, K.J., Pandey, U.B. and Midmore, D.J. 1994. Diseases and insect pests of onion in India. International Symposium on Alliums for the Tropics. Acta Hortic. 358: 265-269.

8. Huq, M.I. and Khan, A.N.A. (2007). Efficacy in-vivo of different fungicides in controlling Stemphylium blight of lentil during 1998-2001. Bangladesh J. Sci. Ind. Res. 42(1): 89-96.

9. Kata, J. (2000). Physical and cultural methods for the management of soil borne pathogens. Crop Prot. 19: 725-731.

10.Kumar, U., Singh, J., Naresh, P. and Singh, R. (2011). Management of Stemphylium blight of garlic through chemicals. Ann. Pl. Protec. Sci. 19 (1): 126128.

11.Kumari, L., Shekhawat, K.S. and Rai, P.K. (2006). Efficacy of fungicides and plant extracts against Alternaria blight of periwinkle. J. Mycol. PI. Pathol. 36(2): 134-137.

12.Kumbhar, C. T., and More, S. M. (2013). Efficacy of triazole fungicides in controlling fruit rot of chilli. Int. $J$. Pl. Prot. 6(2): 257-261.

13. Machenahalli, S. and Nargund, V. B. (2015). Effect of fungicides on the management of die-back and fruit rot of chilli (Capsicum annuum L.). Karnataka J. Agric. Sci. 28(2): 220-223.

14.Miller, M.E., Bruton, B.D. and Amador, J.M. (1986). Effects of number and timing of chlorothalonil applications on onion yield. PI. Dis. 70(9): 875-876.

15.NHRDF. (2015). Area, Production and Productivity of Onion in India (2015-16). Statistics at a Glance. ICAR - Directorate of Onion and Garlic Research. http:/l www.dogr.res.in/index.php/en/download/20downloads/69-statistic

16.Pandey, N.K., Purushottam, Gupta, R.C. and Mishra, R.K. (2008). Management of foliar diseases of onion. Ann. Rep. NHRDF, Nashik, India.

17.Shahiduzzaman, M., Hossain, M. A., and Kundu, N. D. (2015). Efficacy of fungicides to control Stemphylium blight (Stemphylium botryosum) of lentil. Bangladesh J. Agric. Res. 40(2): 229-233.

18.Shahnaz, E., Razdan, V.K., Rezwi, S.E.H., Rather, T.R., Gupta, S. and Andrabi, M. (2012). Integrated disease management of foliar blight disease of onion: A case study of application of confounded factorials. J. Agric. Sci. 5(1): 17.

19.Sharma, S.R. (1986). Effect of fungicidal on purple blotch and bulb yield of onion. Indian Phytopath. 39: 78-82.

20.Singh, D., Dhiman, J.S., Sidhu, A.S., Singh, D.H. and Singh, H. (1992). Current status of onions in India: strategies for disease resistance breeding for sustained production. Onion Newsletter Tropics. 4: 4344.

21.Sunkad, G. and Mesta, R. K. (2010). Field efficacy of some fungicides for effective and economicalcontrol major foliar diseases of groundnut. Karnataka $\mathrm{J}$. Agric. Sci. 18(4).

22.Wheeler, B.E. (1969). An introduction to plant diseases. John Wiley and Sons Ltd, London, UK, pp 43-46. 